\title{
Rapid Transcriptional Down-Regulation of c-myc Expression during Cyclic Adenosine Monophosphate-promoted Differentiation of Leukemic Cells
}

\author{
Arne Slungaard, Dennis L. Confer, and William H. Schubach \\ University of Minnesota Hospitals and Clinics, Department of Internal Medicine, \\ University of Minnesota, Minneapolis, Minnesota 55455
}

\begin{abstract}
Pharmacologic elevation of cyclic AMP (cAMP) promotes growth arrest and differentiation in a variety of transformed mammalian cells, including the HL-60 human promyelocytic leukemia cell line. However, mechanisms underlying this phenomenon are poorly understood. Because cellular oncogenes play a pivotal role in regulating proliferation and differentiation, we examined whether cAMP-promoted differentiation of $\mathrm{HL}-60$ was preceded by a decrease in the expression of $c$-myc, a cellular oncogene both amplified and constituitively expressed in $\mathrm{HL}$ 60. We find that cyclic AMP elevation in HL-60 caused by three different pharmacologic regimens is followed by an abrupt, $>90 \%$ decrease in steady state $c$-myc mRNA levels within $3 \mathrm{~h}$, well before detectable changes in proliferation and differentiation. This decrease, which occurs despite protein synthetic blockade, is attributable to transcriptional down-regulation of $c-m y c$ and is accompanied by changes in chromatin structure near $c-m y c$ promoter sites. Our findings establish that CAMP, a ubiquitous intracellular regulatory messenger previously known only to enhance gene transcriptional activity in higher eukaryotic cells, can also suppress transcription of a cellular oncogene, thereby suggesting a potential mechanism for CAMP-promoted differentiation.
\end{abstract}

\section{Introduction}

Intracellular elevation of the nucleotide cyclic adenosine monophosphate (cAMP), in addition to regulating specific metabolic pathways, elicits such complex changes as growth arrest and differentiation in some transformed mammalian cells-an oftendescribed (1-6) but poorly understood phenomenon (7). Among the cell types which undergo cAMP-promoted differentiation is HL-60 $(8,9)$, a human promyelocytic leukemia cell line (10) that also differentiates along either monocytic or neutrophilic lines when exposed to such chemically diverse agents as dimethylsulfoxide (DMSO) (11), retinoic acid (12), or vitamin $\mathrm{D}_{3}$ (13). Consequently, HL-60 is extensively used as a model for studying normal and leukemic hematopoietic differentiation.

Address reprint requests to Dr. Slungaard, Box 480 UMHC, University of Minnesota Hospital, Harvard St. at East River Rd., Minneapolis, MN 55455. Dr. Schubach's present address is Dept. of Internal Medicine, State U. of New York, Stony Brook, NY 11790.

Received for publication 8 December 1986.

J. Clin. Invest.

(c) The American Society for Clinical Investigation, Inc. 0021-9738/87/05/1542/06 \$1.00

Volume 79, May 1987, 1542-1547
Of particular interest is the attenuated expression of $c-m y c$, a cellular oncogene amplified 10- to 20-fold in HL-60 (14), that accompanies terminal differentiation caused by these three agents $(15,16)$, which suggests a potential role for continuous expression of $c-m y c$ in maintaining a transformed phenotype and preventing maturation. We therefore used HL-60 as a well-characterized model in which to examine the possible involvement of altered cellular oncogene expression in cAMP-promoted differentiation. We find that a surprisingly rapid and abrupt decrease in steady state $c$-myc messenger RNA (mRNA) levels, caused by transcriptional down-regulation and accompanied by $c-m y c$ chromatin structural changes, precedes cAMP-promoted growth arrest and differentiation in HL-60.

\section{Methods}

Materials, cell lines, and probes. Dibutyryl cAMP (dibcAMP) ${ }^{1}$, cholera toxin (CT), isobutylmethylxanthine (IBMX), and actinomycin D were obtained from Sigma Chemical Co. (St. Louis, MO). The source of Bordetella adenylate cyclase toxin (BACT) was a dialyzed 4-M urea extract of intact phase I Bordetella pertussis organisms prepared as previously described (17). HL-60 was obtained from the American Tissue Culture Collection (Rockville, MD) and adapted to grow in Iscove's tissue culture medium that contained $100 \mathrm{U} / \mathrm{ml}$ penicillin and $100 \mu \mathrm{g} / \mathrm{ml}$ streptomycin with $15 \%$ heat-inactivated fetal calf serum. The human $c-m y c$ probe was a 1.6-kb Sst I restriction fragment encompassing the entire first coding exon (see Fig. 4); the $\beta$-actin probe was a $0.7-\mathrm{kb}$ Bam HI-Eco RI fragment containing a $3^{\prime}$ untranslated portion of $\beta$-actin (18); and the human thymidine kinase probe was pTK11 (19).

$R N A$ extraction, dot-blot and northern hybridization. For dot-blot hybridization, total cytoplasmic RNA was extracted (20) from $10^{6}$ cell aliquots of HL-60, transferred onto nitrocellulose (20), and hybridized with nick-translated probes $\left(1-2 \times 10^{8} \mathrm{cpm} / \mu \mathrm{g}\right)(20,21)$. Hybridization conditions were $42^{\circ} \mathrm{C}$ in $5 \times$ standard saline citrate (SSC) and $50 \%$ formamide for $18 \mathrm{~h}$; washing conditions were $65^{\circ} \mathrm{C}$ in $0.1 \%$ sodium dodecyl sulfate (SDS), $0.1 \times$ SSC for $1 \mathrm{~h}$. Audioradiograms were prepared using Kodak XAR film and Kodak Lightening-Plus screens at $-70^{\circ} \mathrm{C}$ for various times. For northern blot hybridization studies, RNA was extracted from $1 \times 10^{7}$ cells using the guanidinium isothiocyanate technique (22), polyadenylated RNA selected on oligothymidylic acid-cellulose affinity columns (23) and $5 \mu \mathrm{g}$ electrophoresed in a $1 \%$ agarose-formaldehyde gel, transferred to nitrocellulose (24), and probed as described above.

In vitro nuclear run-off transcription assay. Nuclei from $5 \times 10^{7} \mathrm{HL}$ 60 cells were incubated in the presence of [ $\left.{ }^{32} \mathrm{P}\right]$ UTP (25), labeled RNA isolated, and $2 \times 10^{6} \mathrm{cpm}$ hybridized to filters (25) to which $5 \mu \mathrm{g}$ of the indicated plasmid DNA had previously been bound (26). Hybridization

1. Abbreviations used in this paper: BACT, Bordetella adenylate cyclase toxin; CFU-GM, colony-forming units of granulocyte-macrophage precursors; CT, cholera toxin; dibcAMP, dibutyryl cAMP; IBMX, isobutylmethylxanthine. 
was carried out at $65^{\circ} \mathrm{C}$ for $36 \mathrm{~h}$ in $10 \mathrm{mM} \mathrm{N}$-Tris[hydroxymethyl]methyl2-aminoethanesulfonic acid, pH 7.4, 0.2\% SDS, 10 mM EDTA, $0.3 \mathrm{M}$ $\mathrm{NaCl}$, and $200 \mu \mathrm{g} / \mathrm{ml}$ Escherichia coli RNA. Filters were washed in 2 $\times \mathrm{SSC}$ at $65^{\circ} \mathrm{C}$ for $1 \mathrm{~h}$ and autoradiograms made.

Actinomycin chase study of c-myc stability. Aliquots containing 5 $\times 10^{6}$ cells were removed 10 and $40 \mathrm{~min}$ after addition of $10 \mu \mathrm{g} / \mathrm{ml}$ actinomycin D. The aliquots were rapidly chilled, pelleted, and washed once in $20 \mathrm{ml}$ ice-cold phosphate-buffered saline. RNA was then immediately extracted by the guanidinium isothiocyanate technique (22), and northern blots were prepared and probed for $c-m y c$ as described above. Hybridization signals were quantitated from autoradiograms by scanning video densitometry.

DNase I hypersensitive site analysis. Nuclei from $1 \times 10^{8}$ cells were washed, resuspended in digestion buffer $(60 \mathrm{mM} \mathrm{KCl}, 15 \mathrm{mM} \mathrm{NaCl}, 15$ $\mathrm{mM}$ Tris, $\mathrm{pH} 7.4,0.5 \mathrm{mM}$ DTT, $0.25 \mathrm{M}$ sucrose, $3 \mathrm{mM} \mathrm{MgCl}$, and $0.05 \mathrm{mM} \mathrm{CaCl}$ ) and a range of DNase I (Worthington Biochemical Corp., Freehold, NJ) concentrations from 0 to $10 \mathrm{U} / \mathrm{ml}$, and incubated $10 \mathrm{~min}$ at $37^{\circ} \mathrm{C}(27)$. Digestion was stopped by the addition of $1 \%$ SDS and $20 \mathrm{mM}$ EDTA. Each sample was then digested with $1 \mathrm{mg} / \mathrm{ml}$ proteinase $\mathrm{K}$ at $37^{\circ} \mathrm{C}$ overnight. DNA was isolated by repeated organic extractions and ethanol precipitation. Samples were then digested to completion with Bgl II, and $10 \mu \mathrm{g}$ was electrophoresed on a $0.8 \%$ agarose gel (27). A graded series of four digestions from each treatment group, chosen by ethidium bromide staining to reflect comparable extents of overall DNA degradation among the three groups, was re-electrophoresed on $0.8 \%$ agarose, hybridized (27) with the $1.6-\mathrm{kb} c-m y c$ probe previously described, and autoradiograms made.

\section{Results}

In preparatory experiments (not shown) we first defined the time course of the cAMP effect upon HL-60 proliferation. Because pharmacologic agents that elevate CAMP may have unrelated, nonspecific effects, in our studies we used three cAMP induction regimens with mutually exclusive mechanisms of action: $(a) .500$ $\mu \mathrm{M}$ dibcAMP, a lipophilic analogue of cAMP that crosses cell membranes; (b) $25 \mathrm{ng} / \mathrm{ml} \mathrm{CT}$, a stimulant of membrane-bound adenylate cyclase with $500 \mu \mathrm{M}$ IBMX, which is a cAMP phosphodiesterase inhibitor; and (c) $150 \mu \mathrm{g}$ protein/ml of a crude bacterial extract containing BACT. This last agent, produced by $B$. pertussis, is a membrane-invasive adenylate cyclase (17) that penetrates a variety of mammalian cells (28), including HL-60 (9), and generates large intracellular accumulations of authentic cAMP from intracellular ATP stores. The three regimens affected HL-60 proliferation identically: pulse $\left[{ }^{3} \mathrm{H}\right]$ thymidine incorporation into TCA-precipitable material was minimally affected through $6 \mathrm{~h}$, but declined to $50 \%$ that of untreated cells by 12 h, $20 \%$ by $24 \mathrm{~h}$, and < 3\% from days 2 through 5 . The similar effects of three cAMP induction regimens demonstrate a cAMPspecific effect upon HL-60 proliferation.

To determine levels of $c-m y c$ mRNA during cAMP-dependent HL-60 differentiation we performed quantitative dot-blot hybridization of total cytoplasmic RNA. In response to the three cAMP induction regimens described above, $c-m y c$ RNA levels decline abruptly by $3 \mathrm{~h}$ and remain $<10 \%$ that of control throughout the assay period of $3 \mathrm{~d}$ (Fig. $1 \mathrm{~A}$ ). The cAMP effect on $c-m y c$ expression is not simply due to generalized RNA degradation because steady state levels of $\beta$-actin are unaffected (Fig. $1 B$ ). The decrease in total cytoplasmic $c$-myc RNA detected in the dot-blot assay reflects polyadenylated RNA levels (Fig. 1 $C)$. This cAMP-dependent decrement in $c$-myc RNA levels does not depend upon ongoing protein synthesis (and, by implication, altered translational expression of other genes) because it occurs
A

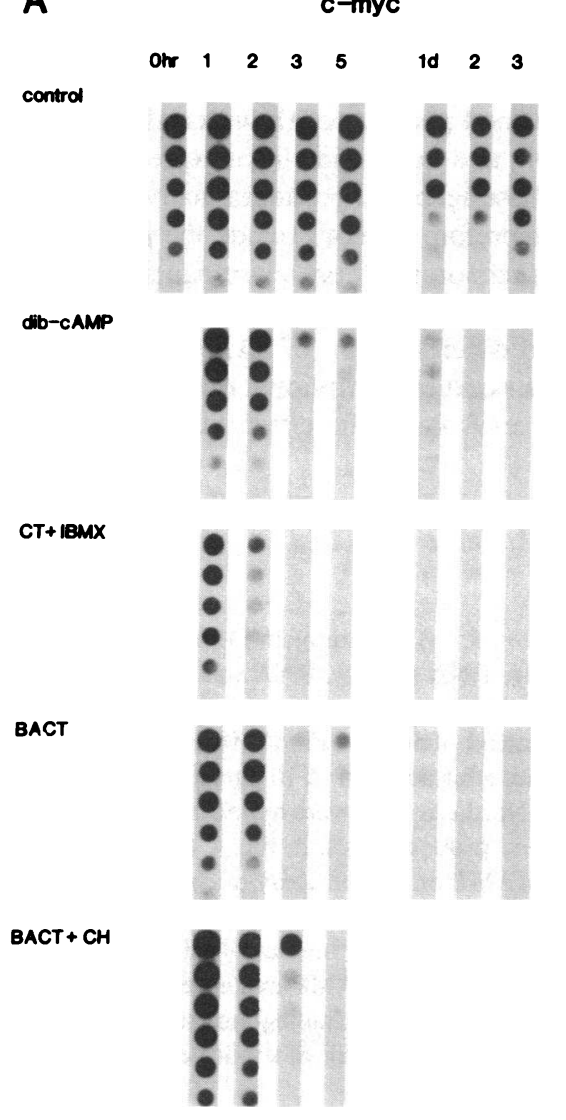

B B-actin

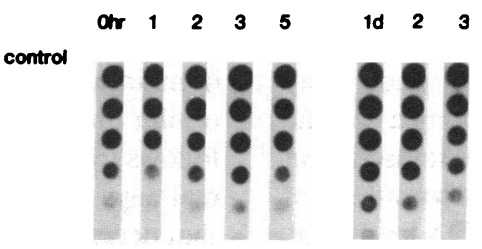

dib-cAMP

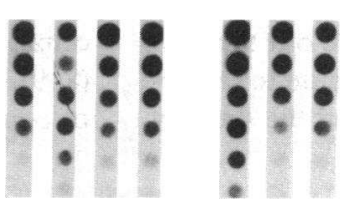

C

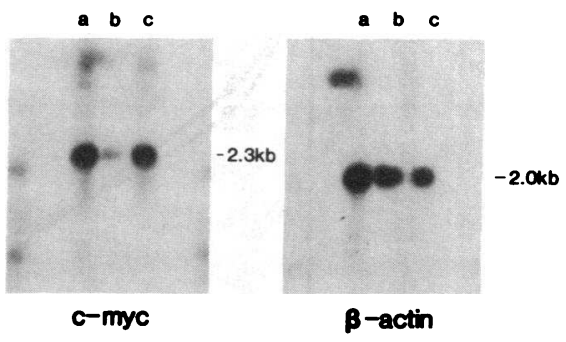

Figure 1. $c$-myc and $\beta$-actin mRNA in HL-60 after CAMP induction. ( $A$ and $B$ ) Cytoplasmic RNA was prepared from $10^{6}$ cell aliquots of HL-60 treated as indicated, serially diluted twofold, and transferred onto nitrocellulose. $(A)$ Dotblots hybridized with human $c-m y c$ probe (map in Fig. 4). Control: culture medium (Iscove's, with 15\% fetal calf serum); dibcAMP: $500 \mu \mathrm{M}$ dibcAMP; CT + IBMX: $25 \mathrm{ng} / \mathrm{ml} \mathrm{CT}$ and $500 \mu \mathrm{M}$ IBMX; BACT: $140 \mu \mathrm{g} / \mathrm{ml}$ protein of a dialyzed urea extract containing BACT; BACT + cycloheximide (CH): $140 \mu \mathrm{g} /$ $\mathrm{ml}$ BACT with $2 \mu \mathrm{g} / \mathrm{ml}$ cycloheximide added $1 \mathrm{~h}$ previously. (B) Blots from $A$ re-probed with a 3 ' untranslated portion of $\beta$-actin. Results were identical for regimens $\mathrm{B}$ and $\mathrm{C}$ (not shown). ( $C$ ) Northern blot of polyadenylated RNA after cAMP induction. Oligo-dT-selected RNA was isolated from cells before treatment $(a)$ and $4 \mathrm{~h}$ after addition of either $500 \mu \mathrm{M}$ dibcAMP $(b)$ or culture medium $(c)$, and northern blots hybridized with the $c$-myc $(A)$ or $\beta$-actin (B and $C$ ) probes described. 


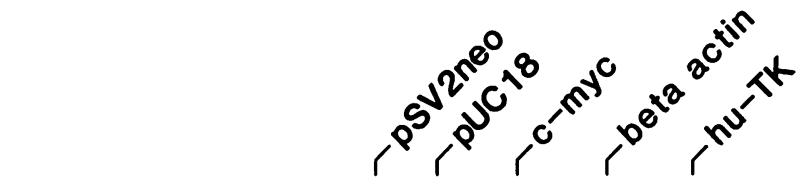

Pretreatment

4h dib-cAMP

\section{4h control}

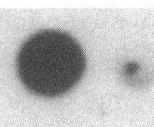

Figure 2. In vitro nuclear runoff transcription. Nuclei from $5 \times 10^{7}$ HL-60 cells before treatment and after $4 \mathrm{~h}$ in the presence or absence (control) of $500 \mu \mathrm{M}$ dibcAMP were incubated with [ $\left.{ }^{32} \mathrm{P}\right] \mathrm{UTP}$, labeled RNA isolated, and $2 \times 10^{6} \mathrm{cpm}$ hybridized to filters to which $5 \mu \mathrm{g}$ of the indicated plasmid DNA had previously been bound and autoradiograms made. Columns designated pSV2neo and pUC18 are vector controls containing no insert; $c$-myc and $\beta$-actin are these intact plasmids containing, respectively, the $c-m y c$ and $\beta$-actin clones described in Fig. 1. hu-TK is a plasmid containing a complementary DNA clone of human thymidine kinase, pTK 11 .

despite the presence of $2 \mu \mathrm{g} / \mathrm{ml}$ cycloheximide, which blocks $>90 \%$ of $\left[{ }^{3} \mathrm{H}\right]$ leucine incorporation into HL-60 cells (Fig. $1 \mathrm{~A}$ ). Cells treated with BACT plus cycloheximide had decreased viability by day 1 , so data beyond $5 \mathrm{~h}$ are not shown; cycloheximide alone induced $c$-myc levels.

$c-m y c$ RNA levels are regulated either at the level of transcription (29) or by modulation of $c-m y c$ RNA degradation (30), which is normally very rapid (half-life of $10 \mathrm{~min}$ ) (31). To assess the former possibility, we used an in vitro nuclear runoff assay that detects the presence of active polymerases along a specific gene (25). After $4 \mathrm{~h}$ of exposure to dibcAMP, $c-m y c$ transcription is suppressed by $>90 \%$ as quantitated by densitometry, an extent commensurate with the decrease in steady state RNA levels (Fig. $2)$. In contrast, transcription of two other genes, $\beta$-actin and thymidine kinase, is relatively unaffected. To rule out the possibility that posttranscriptional alterations contribute to the decrease in steady state $c-m y c$ RNA, we also assayed the stability of $c-m y c$ mRNA by northern blot hybridization of RNA isolated at intervals after the addition of $10 \mu \mathrm{g} / \mathrm{ml}$ actinomycin $\mathrm{D}$ to block RNA synthesis. In cells incubated $4 \mathrm{~h}$ either with or without $500 \mu \mathrm{M}$ dibcAMP, $c-m y c$ mRNA half-life is the same: $\sim 10$ $\min$ (Fig. 3).

Developmental activation of gene transcription is accompanied by changes in chromatin structure. These are detectable both as an overall increase in DNase sensitivity of DNA in coding regions (32) and as localized DNase hypersensitive sites near the $5^{\prime}$ end of the coding region and on regulatory sequences (33). To determine whether such chromatin structural changes also accompany cAMP-dependent transcriptional down-regulation of $c-m y c$, we compared DNase I hypersensitive site patterns of $c-m y c$ at three stages during cAMP-promoted differentiation of HL-60. By $4 \mathrm{~h}$, when $c-m y c$ transcription was first found to be attenuated, dibcAMP-treated cells demonstrated a relative resistance of $c-m y c$ DNA to DNase I digestion when compared with that of untreated cells (Fig. 4). By day 2, after growth arrest and differentiation had occurred, the intensities of hypersensitive sites II and III were markedly decreased relative to those of hypersensitive sites I and V (Fig. 4). Similar changes in c-myc hypersensitive site patterns were seen in cells treated with $C T$ and IBMX (not shown).

\section{Discussion}

The $c-m y c$ gene encodes a nuclear phosphoprotein that may function as a cell cycle-specific "competence factor" permitting traversal of the $G_{1}$ phase of the cell cycle (34). c-myc is constituitively expressed in a variety of transformed cells, including HL60 (14), and transiently expressed during normal hematopoietic differentiation of human granulocyte precursors (35). Moreover, $c-m y c$ expression is attenuated in HL-60 cells terminally differentiated with retinoic acid (15), DMSO (15), and vitamin $D_{3}$ (16), suggesting a potential role for continuous $c-m y c$ expression in maintaining a transformed phenotype. However, the growth inhibition, differentiation, and decline in $c-m y c$ expression that follows treatment with these agents all occur gradually over several days $(29,36)$, and therefore do not exclude the possibility that decreased $c$-myc expression is simply a consequence, not a cause, of growth arrest and differentiation. In contrast, cAMP causes growth arrest and differentiation of HL-60 within $24 \mathrm{~h}$ $(8,9)$. Our finding that a rapid transcriptional down-regulation of $c-m y c$ precedes these cAMP-specific effects supports a per-

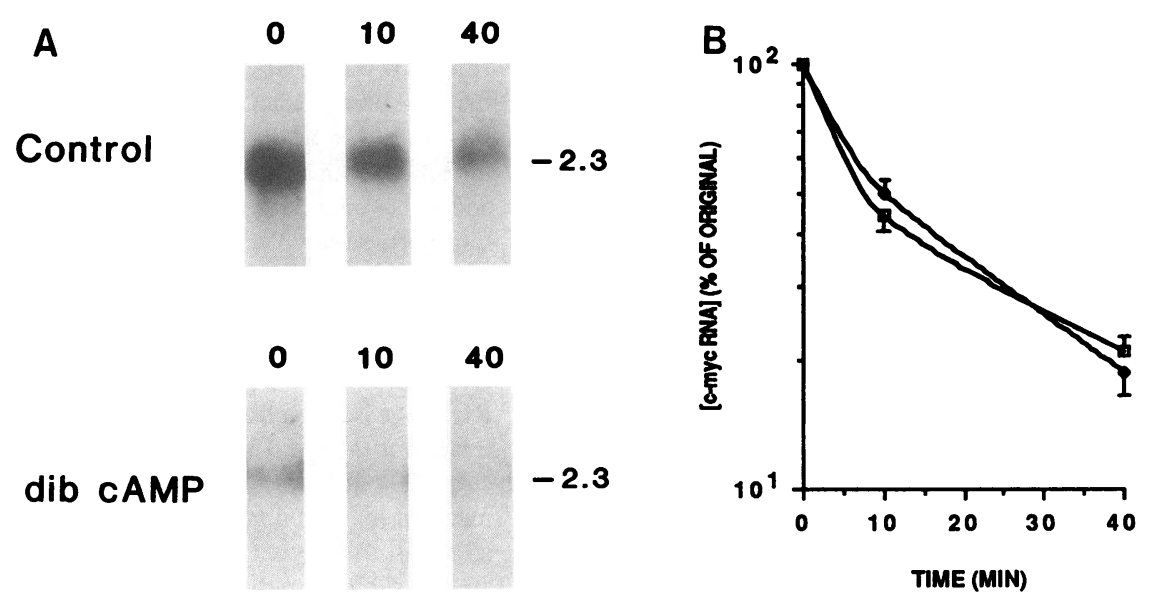

Figure 3. (A) Actinomycin D chase study of $c-m y c$ RNA stability. RNA was isolated from cells incubated $4 \mathrm{~h}$ in the presence or absence (control) of $500 \mu \mathrm{M}$ dibcAMP at the indicated times after addition of $10 \mu \mathrm{g} / \mathrm{ml}$ actinomycin $D$. Northern blots were hybridized with the c-myc probe depicted in Fig. 4. (B) Effect of dibcAMP on rate of decay of $c-m y c$ hybridization signal. Open boxes represent the intensity of the $c-m y c$ signal in control cells, and closed boxes that of dibcAMP-treated cells as quantitated from the autoradiograms shown in $A$. Error bars show the SE of triplicate densitometric determinations. 

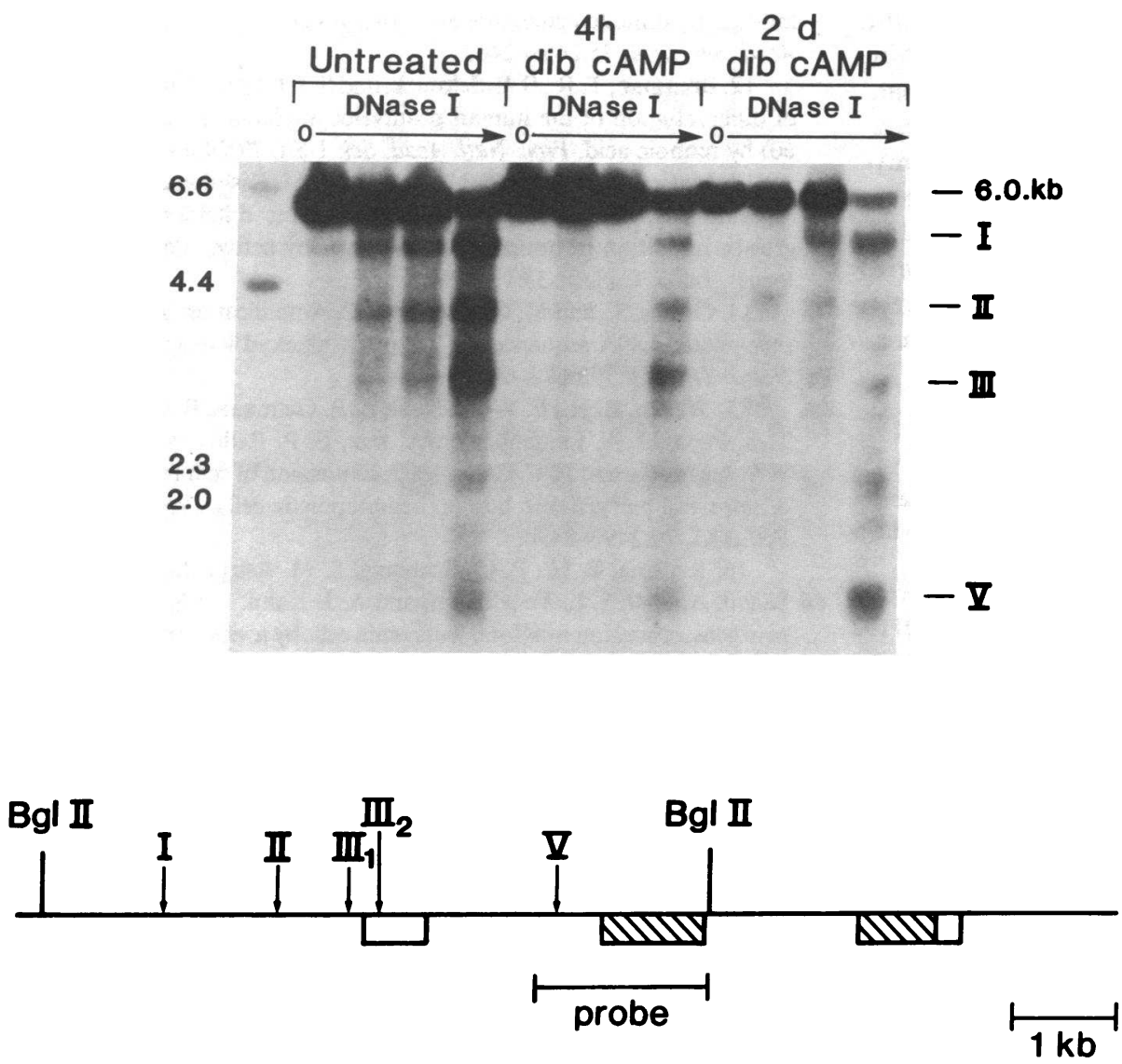

Figure 4. DNase I hypersensitive sites in HL-60 c-myc chromatin after cAMP induction. Nuclei were isolated from 2 $\times 10^{7} \mathrm{HL}-60$ cells before, $4 \mathrm{~h}$ after, and $2 \mathrm{~d}$ after exposure to $500 \mu \mathrm{M}$ dibcAMP and digested with increasing concentrations of DNase I, which are designated by the direction of the arrow. DNA was isolated and exhaustively digested with Bgl II. A graded series of four comparable digestions from each treatment group was electrophoresed in $0.8 \%$ agarose, and probed with the $\mathrm{P}^{32}$-labeled, nick-translated 1.6-kb c-myc probe indicated. The first lane on the left contains size markers. Bgl II generates a 6.0-kb band in DNA from untreated nuclei (see line drawing). With increasing DNase I digestion, specific subbands, representing hypersensitive sites and identified with roman numerals, are generated. Nomenclature for the subbands is that previously used by Siebenlist et al. (38). The minor sites $\mathrm{III}_{1}$ and $\mathrm{III}_{2}$ are not clearly resolved and are labeled III. In the line drawing, open bars indicate untranslated, and cross-hatched bars translated, $c-m y c$ exons. missive or causal role for extinction of $c$-myc expression in promoting functional maturation of this leukemic cell line. Indeed, the recent demonstration that antibodies to the $c$-myc protein suppress DNA synthesis in HL-60 nuclei (37) implies that cAMPdependent attenuation of $c-m y c$ expression can by itself directly cause growth arrest.

Investigating the mechanism behind rapid extinction of c-myc expression in HL-60 after cAMP elevation, we found a transcriptional down-regulation accompanied by diminished expression of DNase I hypersensitive II sites and III $(29,38)$. These sites are located just upstream of, respectively, promoter sequences previously designated as $P_{0}(29)$ or $P_{1}$ and $P_{2}$ (39). Moreover, preliminary experiments utilizing exon-specific probes indicate that down-regulation of $c-m y c$ is caused by a block to transcriptional elongation between exons I and II (unpublished observations). Strikingly similar changes accompany HL-60 differentiation caused by DMSO $(38,40)$ and retinoic acid (29), but occur much more slowly-over days rather than within 4 h. In view of these mechanistic similarities, the relative speed with which cAMP attenuates $c-m y c$ transcriptional activity suggests that DMSO and retinoic acid-structurally unrelated substances with no known role in the regulation of normal cellular functions-might ultimately act through a mechanism dependent upon cAMP, an endogenous intracellular signalling substance. The observation that retinoic acid, DMSO, and phorbol esters also increase nucleosol-associated cAMP-dependent protein kinase activity in HL-60 (41) supports this hypothesis.

The role of cAMP in regulating such cytosolic metabolic pathways as glycogenolysis is well characterized. In contrast, understanding of mechanisms underlying such complex phenom- ena as CAMP-dependent growth arrest and differentiation, which likely involve changes in gene expression, remains rudimentary (7). Though cAMP alters gene expression in mammalian cells (42), previous investigations have only shown cAMP capable of stimulating transcriptional activity of differentiation-specific genes, such as prolactin and growth hormone in rat pituitary cells (43). We demonstrate a rapid, cAMP-specific decrement in HL-60 c-myc RNA levels mediated by transcriptional downregulation-to our knowledge the first example of this phenomenon in higher eukaryotic cells. The detection of concomitant $c-m y c$ chromatin structural changes further emphasizes that cAMP attenuation of $c-m y c$ is effected at the genomic level. Thus, our studies extend previous correlations between exposure to cAMP analogues and decreases in steady state levels of oncogene protein (44) and RNA (45), and raise the possibility that transcriptional modulation of oncogene expression may, in part, mediate CAMP-dependent differentiation in other transformed cell types. One hypothetical mechanism envisions cAMP simultaneously promoting transcription of genes encoding proteins characteristic of terminal differentiation, while repressing transcription of genes, such as $c-m y c$, which may permit continuous proliferation and block differentiation.

Our findings in HL-60 leukemic cells may also have relevance to normal hematopoiesis. Several agents that increase intracellular cAMP, including monocyte-derived prostaglandins of the E series (PGEs), inhibit proliferation of colony-forming units of granulocyte-macrophage precursors (CFU-GM) in a soft agar cloning assay $(46,47)$. Monocytes and macrophages have on this basis been implicated as participating in intrinsic negative feedback control of normal myelopoiesis (47). Human bone 
marrow cells exposed to growth factors that promote CFU-GM growth transiently, but strongly express $c-m y c 24 \mathrm{~h}$ later, when cells morphologically identifiable as promyelocytes predominate (35). cAMP-promoted transcriptional down-regulation of $c-m y c$, were it to occur in normal as well as HL-60 leukemic promyelocytes, could mediate suppression of CFU-GM growth in response to cAMP elevation. Thus, CAMP, which is generated by a receptor-coupled adenylate cyclase complex, may prove to serve as an important second messenger intermediary between extracellular signals and nuclear regulation of oncogene expression.

\section{Acknowledgments}

We thank Kelly Knutson and Molly Johnson for technical assistance, Michael Cole and Larry Kedes for probes, and Carol Taubert for help in preparing this manuscript.

This work was supported by National Institutes of Health grants CA36977 (to Dr. Schubach), AM-01289 (to Dr. Slungaard), and HL-01150 (to Dr. Confer), and by funds from the Minnesota Medical Foundation, the Coleman Leukemia Research Fund, and the Leukemia Research Fund of the University of Minnesota.

Note added in proof. Since this work was completed, Vaulont et al. (1986. J. Biol. Chem. 261:7621-7625) have reported that another mammalian gene, L-type pyruvate kinase, is transcriptionally down-regulated by dibcAMP in rat hepatic cells.

\section{References}

1. Johnson, G. S., R. M. Friedman, and I. Pastan. 1971. Restoration of several morphological characteristics of normal fibroblasts and sarcoma cells treated with adenosine- $3^{\prime}, 5^{\prime}$-cyclic monophosphate and its derivatives. Proc. Natl. Acad. Sci. USA. 68:425-429.

2. Sheppard, J. R. 1971. Restoration of contact-inhibited growth to transformed cells by dibutyryl adenosine 3',5'-cyclic monophosphate. Proc. Natl. Acad. Sci. USA. 68:1316-1320.

3. Prasad, K. N., and A. W. Hsie. 1971. Cyclic AMP and differentiation in vitro induced by dibutyryl adenosine $3^{\prime}, 5^{\prime}$-cyclic monophosphate. Nature New Biol. 233:141-142.

4. Cho-Chung, Y. S., T. Clair, J. S. Bodwin, and B. Berghoffer. 1981. Growth arrest and morphological change of human breast cancer cells by dibutyryl cyclic AMP and L-arginine. Science (Wash. DC). 214:7779.

5. Hagiwara, M., S. M. Pincus, I. L. Chen, B. S. Beckman, and J. W. Fisher. 1985. Effects of dibutyryl adenosine 3',5'-cyclic monophosphate on erythropoietin production in human renal carcinoma cell cultures. Blood. 66:714-717.

6. Friedman, D. L. 1976. Role of cyclic nucleotides in cell growth and differentiation. Physiol. Rev. 56:652-708.

7. Cho-Chung, Y. S. 1980. On the mechanism of cyclic AMP-mediated growth arrest of solid tumors. Adv. Cyclic Nucleotide Res. 12: 111-121.

8. Chaplinski, T. J., and J. E. Niedel. 1982. Cyclic nucleotide-induced maturation of human promyelocytic leukemia cells. J. Clin. Invest. 70: 953-964.

9. Slungaard, A., D. L. Confer, H. S. Jacob, and J. W. Eaton. 1983. Antineoplastic effects of a bacterial adenylate cyclase toxin. Trans. Assoc. Amer. Phys. 46:401-405.

10. Gallagher, R., S. Collins, J. Trujillo, K. McCredie, M. Ahearn, S. Tsai, R. Metzgar, G. Aulakh, R. Ting, F. Ruscetti, and R. Gallo. 1979. Characterization of the continuous, differentiating myeloid cell line (HL60 ) from a patient with acute promyelocytic leukemia. Blood. 54:713733.

11. Collins, S. J., F. W. Ruscetti, R. E. Gallagher, and R. C. Gallo. 1978. Terminal differentiation of human promyelocytic leukemia cells induced by dimethyl sulfoxide and other polar compounds. Proc. Natl. Acad. Sci. USA. 75:2458-2462.

12. Breitman, T. R., S. E. Selonick, and S. J. Collins. 1980. Induction of differentiation of the human promyelocytic leukemia cell line (HL60) by retinoic acid. Proc. Natl. Acad. Sci. USA. 77:2936-2940.

13. Matsui, T., Y. Nakao, N. Kobayashi, M. Kishihara, S. Ishizuka, S. Watanabe, and T. Fujita. 1984. Phenotypic differentiation-linked growth inhibition in human leukemia cells by active vitamin $D_{3}$ analogues. Int. J. Cancer. 33:193-202.

14. Collins, S., and M. Groudine. 1982. Amplification of endogenous myc-related DNA sequences in a human myeloid leukaemia cell line. Nature (Lond.). 298:679-682.

15. Westin, E. H., F. Wong-Staal, E. P. Gelmann, R. Dalla Favera, T. S. Papas, J. A. Lautenberger, A. Eva, E. P. Reddy, S. R. Tronick, S. A. Aaronson, and R. C. Gallo. 1982. Expression of cellular homologues of retroviral onc genes in human hematopoietic cells. Proc. Natl. Acad. Sci. USA. 79:2490-2494.

16. Reitsma, P. H., P. G. Rothberg, S. M. Astrin, J. Trial, Z. BarShavit, A. Hall, S. L. Teitelbaum, and A. J. Kahn. 1983. Regulation of myc gene expression in HL-60 leukaemia cells by a vitamin D metabolite. Nature (Lond.). 306:492-494.

17. Confer, D. L., and J. W. Eaton. 1982. Phagocyte impotence caused by an invasive bacterial adenylate cyclase. Science (Wash. DC). 217: 948-950.

18. Ponte, P., P. Gunning, H. Blau, and L. Kedes. 1983. Human actin genes are single copy for $\alpha$-skeletal and $\alpha$-cardiac actin but multicopy for $\beta$ - and $\gamma$-cytoskeletal genes: $3^{\prime}$ untranslated regions are isotype specific but are conserved in evolution. Mol. Cell Biol. 3:1783-1791.

19. Bradshaw, H. D., Jr., and P. L. Deininger. 1984. Human thymidine kinase gene: Molecular cloning and nucleotide sequence of a cDNA expressible in mammalian cells. Mol. Cell Biol. 4:2316-2320.

20. White, B. A., and F. C. Bancroft. 1982. Cytoplasmic dot hybridization: Simple analysis of relative mRNA levels in multiple small cell or tissue samples. J. Biol. Chem. 257:8569-8572.

21. Rigby, P. W. J., M. Dieckmann, C. Rhodes, and P. Berg. 1977. Labeling deoxyribonucleic acid to high specific activity in vitro by nick translation with DNA polymerase I. J. Mol. Biol. 113:237-251.

22. Ullrich, A., J. Shine, J. Chirgwin, R. Pictet, E. Tischer, W. J. Rutter, and H. M. Goodman. 1977. Rat insulin genes: Construction of plasmids containing the coding sequences. Science (Wash. DC). 196: 1313.

23. Aviv, H., and P. Leder. 1972. Purification of biologically active globin messenger RNA by chromatography on oligothymidylic acid-cellulose. Proc. Natl. Acad. Sci. USA. 69:1408-1412.

24. Thomas, P. S. 1980. Hybridization of denatured RNA and small DNA fragments transferred to nitrocellulose. Proc. Natl. Acad. Sci. USA. 77:5201-5205.

25. Linial, M., N. Gunderson, M. Groudine. 1985. Enhanced transcription of $c-m y c$ in bursal lymphoma cells requires continuous protein synthesis. Science (Wash. DC). 230:1126-1132.

26. Kafatos, F. C., C. W. Jones, and A. Efstratiadis. 1979. Determination of nucleic acid sequence homologies and relative concentrations by a dot hybridization procedure. Nucleic Acids Res. 7:1541-1552.

27. Schubach, W., and M. Groudine. 1984. Alteration of $c-m y c$ chromatin structure by avian leukosis virus integration. Nature (Lond.). 307: 702-708.

28. Confer, D. L., A. Slungaard, E. Graf, S. S. Panter, and J. W. Eaton. 1984. Bordetella adenylate cyclase toxin: Entry of bacterial adenylate cyclase into mammalian cells. Adv. Cyclic Nucleotide Res. 17: 183-187.

29. Bentley, D. L., and M. Groudine. 1986. A block of elongation is largely responsible for decreased transcription of $c-m y c$ in differentiated HL-60 cells. Nature (Lond.). 321:702-706.

30. Dani, Ch., N. Mechti, M. Piechaczyk, B. Lebleu, Ph. Jeanteur, and J. M. Blanchard. 1985. Increased rate of degradation of $c-m y c$ mRNA in interferon-treated Daudi cells. Proc. Natl. Acad. Sci. USA. 82:48964899. 
31. Dani, Ch., J. M. Blanchard, M. Piechaczyk, S. El Sabouty, L. Marty, and Ph. Jeanteur. 1984. Extreme instability of myc mRNA in normal and transformed human cells. Proc. Natl. Acad. Sci. USA. 81: 7046-7050.

32. Groudine, M., and H. Weintraub. 1982. Propagation of globin DNAase I-hypersensitive sites in absence of factors required for induction: A possible mechanism for determination. Cell. 30:131-139.

33. McGinnis, W., A. W. Shermoen, J. Heemskerk, and S. K. Beckendorf. 1983. DNA sequence changes in an upstream DNase I-hypersensitive region are correlated with reduced gene expression. Proc. Natl. Acad. Sci. USA. 80:1063-1067.

34. Kaczmarek, L., J. K. Hyland, R. Watt, M. Rosenberg, and R. Baserga. 1985. Microinjected $c-m y c$ as a competence factor. Science (Wash. DC) 228:1313-1315.

35. Gowda, S. D., R. D. Koler, and G. C. Bagby, Jr. 1986. Regulation of $c-m y c$ expression during growth and differentiation of normal and leukemic human myeloid progenitor cells. J. Clin. Invest. 77:271-278.

36. Filmus, J., and R. N. Buick. 1985. Relationship of $c-m y c$ expression to differentiation and proliferation of HL-60 cells. Cancer Res. 45: 822-825.

37. Studzinski, G. P., Z. S. Brelvi, S. C. Feldman, and R. A. Watt. 1986. Participation of $c-m y c$ protein in DNA synthesis of human cells. Science (Wash.). 234:467-470.

38. Dyson, P. J., T. D. Littlewood, A. Forster, and T. H. Rabbitts. 1985. Chromatin structure of transcriptionally active and inactive human c-myc alleles. EMBO (Eur. Mol. Biol. Organ.) J. 4:2885-2891.

39. Siebenlist, U., L. Hennighausen, J. Battey, and P. Leder. 1984.
Chromatin structure and protein bindings in the putative regulatory region of the c-myc gene in Burkitt lymphoma. Cell. 37:381-391.

40. Grosso, L. E., and H. C. Pitot. 1985. Transcriptional regulation of $c-m y c$ during chemically induced differentiation of HL-60 cultures. Cancer Res. 45:847-850.

41. Elias, L., and T. Stewart. 1984. Subcellular distribution of cyclic adenosine $3^{\prime}: 5^{\prime}$-monophosphate-dependent protein kinase during the chemically induced differentiation of HL-60 cells. Cancer Res. 44:30753080.

42. Nagamine, Y., and E. Reich. 1985. Gene expression and cAMP. Proc. Natl. Acad. Sci. USA. 82:4606-4610.

43. Murdoch, G. H., M. G. Rosenfeld, and R. M. Evans. 1982. Eukaryotic transcriptional regulation and chromatin-associated protein phosphorylation by cyclic AMP. Science (Wash. DC). 218:1315-1317.

44. Huang, F. L., and Y. S. Cho-Chung. 1984. Hormone-regulated expression of cellular $\operatorname{ras}^{\mathrm{H}}$ oncogene in mammary carcinomas in rats. Biochem. Biophys. Res. Commun. 123:141-147.

45. McCachren, S. S., Jr., J. Nichols, R. E. Kaufman, and J. E. Niedel. 1986. Dibutyryl cyclic adenosine monophosphate reduces expression of c-myc during HL-60 differentiation. Blood. 68:412-416.

46. Taetle, R., and A. Koessler. 1980. Effects of cyclic nucleotides and prostaglandins on normal and abnormal human myeloid progenitor proliferation. Cancer Res. 40:1858-1862.

47. Kurland, J. I., R. S. Bockman, H. E. Broxmeyer, and M. A. S. Moore. 1978. Limitation of excess myelopoiesis by the intrinsic modulation of macrophage-derived prostaglandin E. Science (Wash. DC). 199:552-555. 